\title{
DOI https://doi.org/10.30525/978-9934-26-041-4-44
}

\section{ПРО «ВІЧНІ» ДУХОВНІ ЦІННОСТІ ПЕДАГОГІКИ (ЗА ІСПАНСЬКИМИ ДЖЕРЕЛАМИ МЕЖІ ХІХ - ХХ СТ.)}

\author{
Зайченко Н. I. \\ доктор педагогічних наук, \\ професор кафедри загальної та прикладної психологї \\ ПВНЗ «Інститут екології економіки і права» \\ м. Київ, Украӥна
}

Теперішня освітня криза в Україні, викликана перманентними від часу політичних подій 2013 - 2014 років реформаторськими змінами у структурі освітньої системи й у змісті освіти, значно поглибилася унаслідок різних модифікацій в організації педагогічного процесу, чинених українським урядом через коронавірусну загрозу населенню. Українська педагогічна спільнота, зіткнувшись із новими викликами, за відносно короткий проміжок історичного часу мала не просто цілковито переорієнтовуватися на інакші (інноваційні, переважно дистанційні, високотехнологічні) форми навчання, але й кардинальним чином самозмінюватися, передусім у сенсах світоглядних. У теперішніх умовах педагог перетворився на раба інформаційної стихії, він перебуває під постійним тиском хаотичного навального потоку інформації, яка здебільшого виявляється потрібною у реальності не більше, ніж на кілька тижнів. Практична необхідність постійного відстеження викладацьким загалом штучних новоутворень в українському правописі, не завжди виправданих переінакшень в історичному наративі, не обгрунтованих із позиції наукової доказовості свавільних заборон тих чи інших художніх творів змушує сучасних педагогів відволікатися від істотних, ключових питань освітньовиховного процесу; і часто-густо це відволікання обертається утратою «Грунту під ногами» - фундаментальної опори практичної педагогіки на «розумне, добре, вічне». Проте й у XXI столітті, незважаючи на складність «безпрецедентних» викликів часу, учитель має залишатися особистістю, що передбачає на елементарному рівні - усвідомлення i розуміння педагогом того, що він спричиняє власними словами та діями у життях вихованців, а на вищому рівні - творення із них людяних істот. Маючи багатовіковий історичний досвід відстоювання $\mathrm{i}$ захисту освітянами різних країн правди духовної педагогічної традиції, українська учительська спільнота не повинна забувати ці приклади, а 
брати їх на озброєння, щоби «вічно» цінне не затьмарювалося сьогохвилинною оманою у покликаних битися педагогікою серцях.

На межі XIX - XX ст. визначні іспанські педагоги доєдналися до регенераціоністського сподвижницького руху інтелектуалів за «нову Іспанію» - освічену, культурну, цивілізовану, а дехто з них (Хоакін Коста, Ніколас Сальмерон, Мігель де Унамуно) - уособили цей рух. В іспанській пресі розгорнулася широкомасштабна полеміка стосовно народної освіти, залунали численні гасла про «єдину школу», «нову школу», «світську освіту», «народні університети» тощо. Народ має право на освіту, держава повинна забезпечити це право, коли вона прагне зберегти свою державність, - це провідна ідея іспанського інтелектуального регенераціоністського руху межі XIX - XX віків. Іспанські педагоги доводили, що міць освіти - у її правді, у іiї здатності відкривати людській душі об'єктивний світ, а у самій людині розкривати духовну природу розуму.

У статті «Національна освіта» (1890р.) Леон Вега зазначав, що тверде національне виховання необхідне в Іспанії передовсім для консолідації та зміцнення демократичних ідеалів. Саме народна освіта необхідна нині для досягнення справжньої свободи. «Наш дух, керований тривалий час деспотизмом та нетерпимістю, став упередженим i лакейським, скривдив наш розум, послабив волю i змінив характер», - констатував педагог [1, с. 1].

Нині першочерговим завданням держави $\epsilon$ справа формування людей із вільним мисленням, для цієї гігантської справи - необхідна освіта. Ця освіта має розкривати людський талант, а не просто наповнювати учнів корисними знаннями. Школа як інституція виховна має забезпечити повноцінне розвинення усіх здібностей людини, вона має дати учням загальне виховання, духовне і гуманне. «Виховувати означає настановити на життєвий шлях, пробудити розум, направити волю, відчинити усі двері до доброго, істинного і красивого та повністю зупинити розвинення поганого, фальшивого, понівеченого», підкреслював Леон Вега [1, с. 1].

У підручнику Пруденсіо Відаля Хіменеса стверджувалося про те, що виховання має на меті «підготувати покоління [людей] до суспільного порядку, в якому вони існуватимуть, і відповідно підготувати людину, щоб вона змогла повністю виконати своє призначення у житті, а також досягти останньої мети, задля якої вона була створена» [2, с. 9].

Ознакою правильного виховання стане те, що людина постійно спрямовуватиметься на добрі діяння. Результати правильного виховання - «спокій у цьому житті і щастя в іншому» [2, с. 13]. 
За педагогічним настановленням Пруденсіо Відаля Хіменеса, щастя полягає у тому, щоби робити якомога більше добра і не допускати лиха. Людина має діяти відповідно до того, як вимагає іiі свідомість, а свідомість виникає тоді, коли мораль впливає на дії людини. «Щоби досягти повного щастя, необхідно мати живу і чисту віру, а це означає цілковите слідування істинам християнської релігії, точне виконання іiї правил та ставлення із великим презирством до порушення традицій та безбожжя», - підсумовував педагог [2, с. 201].

Освітянин Едуардо Санс Ескартін висловлював думку про те, що у виховному процесі недостатньо спиратися виключно на розвинення розуму, необхідно зміцнювати i дух особистості. А для цього першорядним стане формування моральної свідомості. «Не так важливо пізнавати багато, як пізнавати правильно. У навчальних предметах треба більше дбати про якість, аніж про кількість. Наука, яка не покращує наших прихильностей, яка не озброює нас для боротьби за життя, яка не направляє нас до добра, є наука фальшива і пагубна. Не $є$, як зазвичай вірять, народи сильніші тим, що багато освічені, але $є$ сильніші тим, що краще освічені. I ця якість освіти визначається не тільки правильним спрямуванням пізнання, розуміння, гармонії теорії та практики, але й основним чином - морального елемента, який уможливлює перетворення знання на дію, особистого інтересу на обов'язок», - проголошував педагог [3, с. 9].

Видатний іспанський педагог Педро де Алькантара Гарсія у науковій праці «Компендіум теоретично-практичної педагогіки» (Мадрид, 1891 р.) зауважував, що душа дитини не представляє собою vaso vacio (iсп. «порожній сосуд») або tabula rasa (лат. «чиста дошка»), що необхідно наповнювати або на чому необхідно щось довго нашаровувати. Виховання душі дитини полягає не в тому, щоб дати ій талант чи нав'язати доброчинності, виховання - це праця, яка не робить нічого більшого за розвинення даного людині природою. Впливова сила виховання спрямована на перетворення людської природи. Виховання творить «другу природу», коли вступає у боротьбу з поганими нахилами, коли визволяє людську істоту з рабства тваринної істотності. Виховання - це спосіб олюднення - підготовлення людини для виконання нею різних діяльностей, котрі в індивідуальному, родинному, суспільному модусах конституюють людське життя [4, с. 3].

Педагог Грегоріо Еррайнс у «Трактаті $з$ антропології і педагогіки» (Мадрид, 1896 р.) застерігав: «Виховання не повинно переслідувати якісь часткові чи оманливі цілі, а прагнути до цілісної, справжньої, наміченої Вищим Майстром, мети - здійснення свого особливого призначення кожним із створінь, долі, яку людина не попиратиме святотатственно, а поважатиме, слідуватиме їй» [5, с. 12]. 
Викладач педагогіки Валенсійської вищої учительській школи Гало Рекуеро Гарсія називав «вічною» духовною цінністю педагогіки красу. За міркуванням педагога, краса може бути фізичною, розумовою і моральною. Перша - це краса матеріальних речей, вона сприймається відчуттями, наприклад, при спогляданні квітів. Розумова краса - в істині, яка пізнається розумом, а моральна - у величині добра, яке проявляється у благородних справах [6, с. 286-287].

«Краса, добро і істина - немовби промені світла, яке йде від трьох здібностей душі. < ..> Любов до краси рівноцінна любові до добра. Та ж любов направляє нас іноді до морального героїзму i навіть патріотичного», - наголошував Гало Рекуеро Гарсія [6, с. 288].

Таким чином, відповідно до змісту іспанських джерел із педагогіки 1890 - 1910-х років іспанські педагоги на межі XIX - XX ст. рішуче захищали «вічні» духовні педагогічні цінності i доводили, що педагогіка має спрямовуватися на розкриття людського у людині, іiі талантів, іiі розумових, моральних, естетичних здібностей, даних людській істоті від природи. Усілякі нав'язування, перешкоджання i експериментування із людською природою матимуть негативні наслідки вже у недалекому прийдешньому. Педагогіка має передовсім вивчати закономірності розвитку людської природи і виховувати людину узгоджено з ними. Учитель - це поводир душі, наставник розуму, натхненник добра. Віки плинні - істини вічні...

\section{Література:}

1. Vega L. La educacion nacional. La Justicia. Madrid, Jueves 23 de octubre de 1890. № 1024, año III. P. 1.

2. Vidal Jimenez P. La aurora de la niñez. Libro moral de lectura para niños y niñas. Guadalajara : Establecimiento Tipografico de Antero Concha, 1908. $210 \mathrm{p}$.

3. Sanz y Escartin E. La educacion moral. Madrid : Imprenta de E. Raso Lopez, 1910. 60 p.

4. Alcantara Garcia P. Compendio de Pedagogia teorico-practica. Madrid : Libreria de la Viuda de Hernando y C., 1891. 440 p.

5. Herrainz G. Tratado de Antropologia y Pedagogia. Madrid : Libreria de la Viuda de Hernando y C., 1896. 565 p.

6. Recuero Garcia G. Pedagogia. Educacion General. T. 1. Valencia : Establecimiento tipografico «La Gutenberg», 1912. 363 p. 